\title{
22. SEDIMENTOLOGICAL RESPONSE OF AN OUTER-SHELF, UPPER-SLOPE SEQUENCE TO RAPID CHANGES IN PLEISTOCENE EUSTATIC SEA LEVEL: HOLE 820A, NORTHEASTERN AUSTRALIAN MARGIN ${ }^{1}$
}

\author{
F.M. Peerdeman ${ }^{2}$ and P.J. Davies ${ }^{3}$
}

\begin{abstract}
A principal objective at Site 820, situated on the outer shelf, upper slope of the northeastern Australian continental margin, was to test the relationships between changes in Pleistocene sea level and sedimentary packages produced on a mixed carbonate-siliciclastic continental margin. To this end, we have examined the downcore distribution of grain size, magnetic susceptibility, and calcium-carbonate content throughout Hole 820 A and, in particular, the top 35 meters below the seafloor (mbsf). These data are compared with variations in the oxygen-isotope signal defined for the same hole and are interpreted as indicating sea-level oscillations. The distribution of sand, mud, calcium carbonate of the mud fraction and total sample, and magnetic susceptibility during the last $20,000 \mathrm{yr}$ defines the position of a sea-level regression (41,000-18,000 yr B.P.), a lowstand, early (18,000-9,400 yr B.P.) and late transgressions $(9400-4900 \mathrm{yr}$ B.P.), and a highstand ( $4900 \mathrm{yr}$ to the present).

The regression is seen first in a high-carbonate content peak. Calcium carbonate constituents mainly comprise skeletal carbonate grains, with abundant planktonic and benthic foraminifers, and lime muds. The lowstand is characterized by a maximum abundance of the sand fraction, which contains dominantly skeletal carbonate grains and a minor abundance of lithoclasts. Sand-sized terrigenous sediments are proposed to have bypassed the continental shelf during a lowstand of sea level. Sedimentation rates throughout the regression and lowstand are low $(3.0 \mathrm{~cm} / \mathrm{k} . \mathrm{y}$.). The early transgression, marked by highest values in magnetic susceptibility, displays a rapid increase in sedimentation rate that coincided with an increase in terrigenous mud. Highest sedimentation rates of $82.3 \mathrm{~cm} / \mathrm{k} . \mathrm{y}$. occurred during the late transgression, with increasing percentages of lime-mud.

A decrease in noncarbonate constituents in the mud fraction during the late transgression and highstand of sea level is thought to be the result of restricted inner-shelf sedimentation of terrigenous sediments.

The same relationship is also seen in the major sea-level oscillation, which is interpreted as isotope stage 6.
\end{abstract}

\section{INTRODUCTION}

Hole 820A was sited at the outer edge of the northeastern Australian continental margin $\left(16^{\circ} 38.22^{\prime} \mathrm{S}, 146^{\circ} 18.22^{\prime} \mathrm{E}\right)$ in a water depth of $280.6 \mathrm{~m}$ (Fig. 1). The hole had a total recovery of $145.8 \mathrm{~m}$ and represents one of five ODP drill holes located at three sites, immediately in front of the present-day Great Barrier Reef, that were drilled to define the relationship between changes in sea level, sedimentary sequences, and seismic geometries (i.e., the response of an outer-shelf, upper-slope sequence to rapid oscillations of Pleistocene sea level).

A suite of lithologic and other shipboard results from Holes $820 \mathrm{~A}$ and 820B (Davies, McKenzie, Palmer-Julson, et al., 1991) shows a well-developed cyclicity within the sediments in the upper 150.7 mbsf. Shipboard analyses showed that this sequence covers a time span from the present to $1.27 \mathrm{Ma}$ (CN15-CN13b) in which rapid changes in global sea level, thought to have been driven by climatic oscillations, were postulated to have had a dominant influence on shelf sedimentation.

To understand the effect of rapid changes in global sea level/climate on the observed cyclicity in sedimentation through Hole $820 \mathrm{~A}$, we have examined the downcore distribution of grain size, magnetic susceptibility, and calcium-carbonate content. In particular, we examined the top $35 \mathrm{~m}$ of the hole, because this contains an extremely high-resolution section of carbonate slope sediments and represents the time span of reasonably well-understood oscillations in sea level during the past 140,000 yr. Therefore, our aim has been to characterize the actual sediment response of the northeastern Australian margin with respect to known sea-level changes.

\footnotetext{
'McKenzie, J.A., Davies, P.J., Palmer-Julson, A., et al., 1993.Proc. ODP, Sci. Results, 133: College Station, TX (Ocean Drilling Program).

${ }^{2}$ Research School of Earth Sciences, Australian National University, Canberra, Australia.

${ }^{3}$ Department of Geology and Geophysics, University of Sydney, Sydney, Australia.
}

\section{METHODS}

In this study, samples were taken every $20 \mathrm{~cm}$, with the exception of the section from 130.75 to $121.5 \mathrm{mbsf}$, in which a poorly sorted bioclastic wackestone to floatstone, underlain by an unconsolidated clayey wackestone, did not allow for regular sampling intervals. On the average, each sample spans a time of $600 \mathrm{yr}$.

\section{Magnetic Susceptibility}

Initial, low-field magnetic susceptibility measurements on all specimens throughout Hole 820A were obtained using a Bartington Instruments' MS system calibrated using the house-standard of the Palaeomagnetic Laboratory at Black Mountain, Canberra. The noise level of the Bartington MS system reached during measurements was approximately $5 \times 10-8 \mathrm{cgs}$, and reproducibility of the standards was almost $0.4 \mu \mathrm{G} \mathrm{Oe}^{-1}$. Measurements have been made in cgs units $(0.1)$ range and are quoted per unit volume in units of microgauss per oersted $\left(\mu \mathrm{G} \mathrm{Oe}{ }^{-1}\right)$.

\section{Grain-size and Calcium-carbonate Analysis}

The distribution of mud and sand $( \pm 63 \mu \mathrm{m})$ has been determined in all samples throughout Hole $820 \mathrm{~A}$. Each sample of approximately 15 to $20 \mathrm{~g}$ was disaggregated in Milli- $\mathrm{Q}^{(\mathrm{TM})}$ ultrapure $\mathrm{H}_{2} \mathrm{O}$ and sieved over a $63-\mu \mathrm{m}$ mesh. Subsequently, each fraction was dried and weighed. The sand fraction was dried in an oven at $50^{\circ} \mathrm{C}$, while the mud fraction was centrifuged at $9000 \mathrm{rpm}$ for $10 \mathrm{~min}$, using a RC5C Sorvall Instruments' ultracentrifuge, dried in a freeze-drier overnight, and weighed. The weights were used to calculate the percentage of mud and sand.

Calcium-carbonate percentages were analyzed in the following way. Hydrochloric acid (approximately $10 \mathrm{~mL}$ ) was added to $0.5 \mathrm{~g}$ of sample until fully dissolved. The sample residue and acid were separated using the ultracentrifuge $(5000 \mathrm{rpm}$ for $5 \mathrm{~min})$. Subse- 


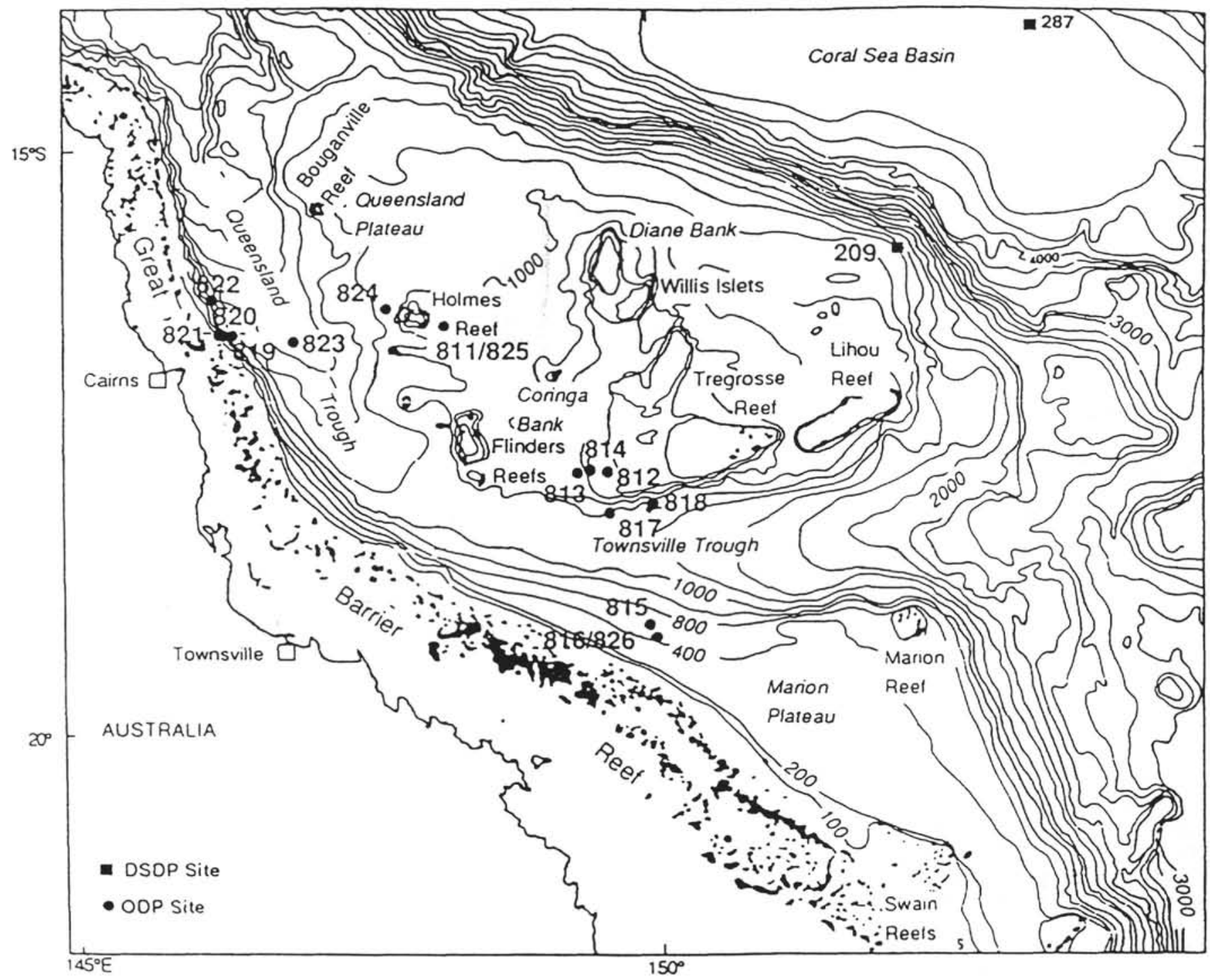

Figure 1. Locality map showing the principal bathymetric features of the northeastern Australian continental margin and the position of Hole $820 \mathrm{~A}$, east of Cairns. Bathymetry in meters.

quently, the acid was siphoned off with a pipette, and the residue rinsed with Milli-Q water, dried in a freeze-drier overnight, and weighed. The initial weight of the sample and weight of its residue were used to calculate the percentage of calcium carbonate.

\section{Stable Oxygen Isotopes}

Stable oxygen isotope values for Hole 820A have been determined on the planktonic species Globigerinoides ruber and are presented and discussed in detail in Peerdeman et al. (this volume). Analyses are expressed as per mil deviation $(\delta)$ from the PDB standard (Epstein et al., 1953). Analytical precision of the working standard (M-2 Bulk, 1991 ) during measurements was $0.02 \%$ for oxygen. Reproducibility of solid NBS 19 standard $( \pm 150 \mu \mathrm{g})$, prepared for measurement by the carbonate preparation device, is $0.05 \%$.

\section{Radiocarbon Dating}

Radiocarbon dating of 10 samples in the upper $10 \mathrm{~m}$ of Hole $820 \mathrm{~A}$ was performed by the Waikato Radiocarbon Laboratory in New Zealand. For each measurement, 20 to $30 \mu \mathrm{g}$ of planktonic and benthic foraminifers were hand-picked from the larger than $250-\mu \mathrm{m}$ fraction.
Each sample was cleaned in Milli- $\mathrm{Q}^{(\mathrm{TM})}$ ultrapure water, using an ultrasonic bath for approximately $1 \mathrm{~min}$ to remove fine-fraction contamination, and the water with the fine fraction in suspension was siphoned off with a pipette. This procedure was repeated five times. Subsequently, the foraminifers were rinsed over a $125-\mu \mathrm{m}$ nylon mesh again with Milli-Q water and visually inspected for any remaining contamination. The radiocarbon dates represent the conventional radiocarbon age before present.

\section{RESULTS}

The results of isotopic variation in the top $135 \mathrm{~m}$ of Hole $820 \mathrm{~A}$ are shown in Figure 2 and are reported and interpreted elsewhere in this volume (Peerdeman et al., this volume). The data for shore-based analyses of the weight-percentage of the sand and silt fraction ( $>63$ $\mu \mathrm{m})$ and magnetic susceptibility also are shown in Figure 2.

The percentage of sand throughout Hole $820 \mathrm{~A}$ varies abruptly in a cyclic manner, from $10 \%$ to $60 \%$. Sediments having a low percentage of sand predominantly contain fine bioclastic wackestones, with planktonic foraminifers being the dominant bioclastic constituent. Other bioclastic particles are pteropod and coral fragments, benthic foraminifers, ostracoda, and molluscan. Sediments having high per- 


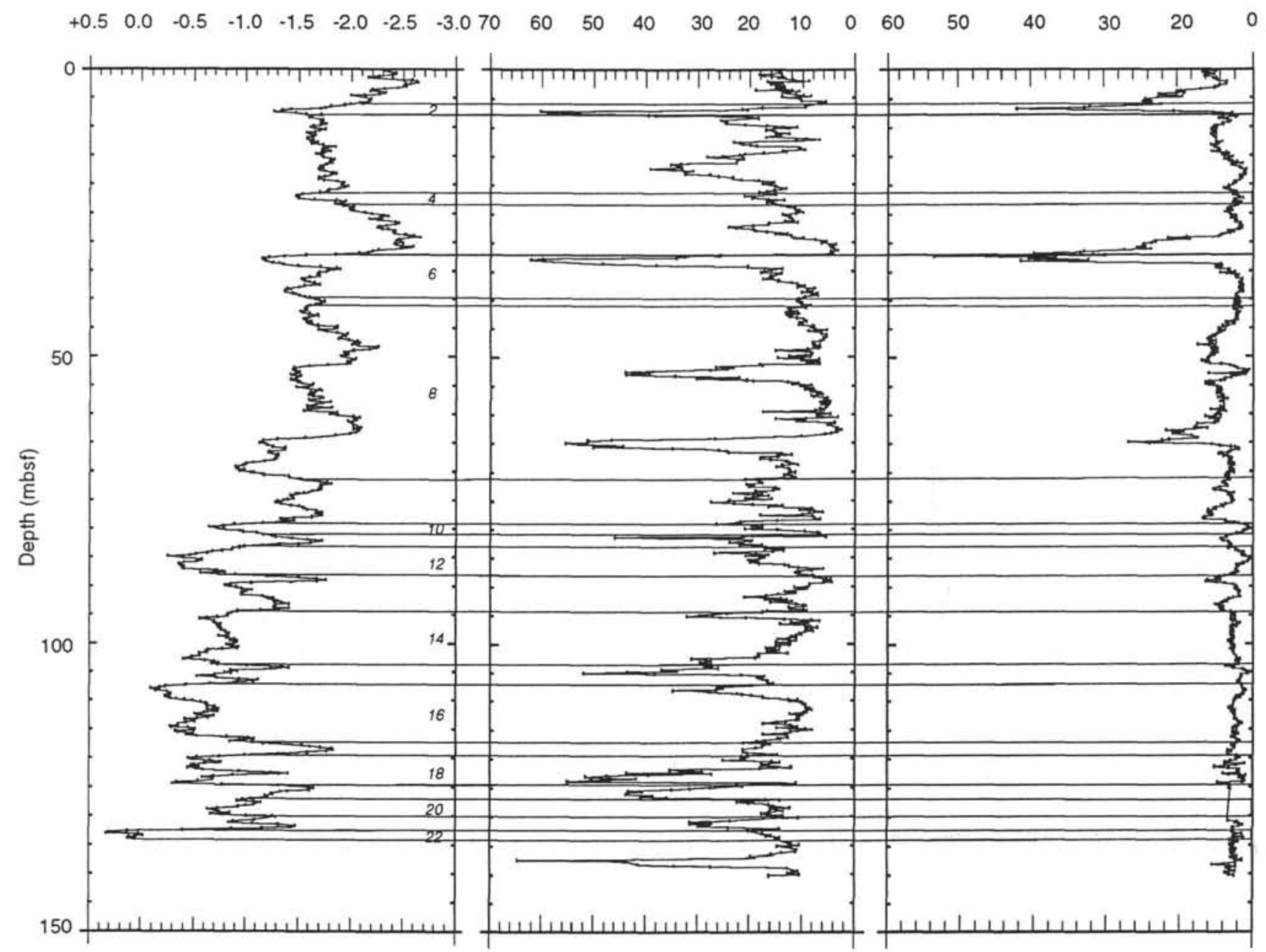

Figure 2. Oxygen-isotope signal, as discussed and interpreted in Peerdeman et al. (this volume), compared to abundance of sand and magnetic susceptibility for the upper $135 \mathrm{mbsf}$ of Hole $820 \mathrm{~A}$. The numbers in the left diagram represent successive oxygen-isotope stages.

centages of sand are coarse packstones with the same composition as the fine wackestones, and additional minor proportions of bryozoan fragments, rhodoliths, and minor abundances (less than 1\%) of nonskeletal carbonate particles.

The noncarbonate portion of all sediments is restricted to the mud fraction, with clay and silt- to very fine sand-sized quartz and feldspar (Feary and Jarrard, this volume) as the main component.

For the upper $65 \mathrm{~m}$ of Hole $820 \mathrm{~A}$, a reasonable correlation (corr. coeff. of +0.4 ) can be seen between the $\delta^{18} \mathrm{O}$ signal and the variations in sand. Enriched values of $\delta^{18} \mathrm{O}$ coincide with high percentages of sand, while light values of $\delta^{18} \mathrm{O}$ correlate with low percentages of sand. Below 65 mbsf, however, the correlation between the sand fraction and the $\delta^{18} \mathrm{O}$ signal becomes less obvious, with some intervals (oxygen-isotope stages 15 through to 22 ) showing the inverse correlation to that seen in the upper $65 \mathrm{~m}$.

Similarly, a distinct change in correlation between the magnetic susceptibility takes place at about 65 mbsf. This change is described in full detail by Barton et al. (this volume).

The analyses of stable-oxygen isotopes, grain size, calcium-carbonate content of the total sample and for the mud fraction, and magnetic susceptibility of the upper $10 \mathrm{~m}$ of Hole $820 \mathrm{~A}$ are presented in Table 1.
Through comparison with the deep-sea signal, Peerdeman et al. (this volume) interpret the isotope signal as a high-resolution signal of climate and changes in sea level off northeastern Australia. To corroborate this for oxygen-isotope stages 1 and 2, 10 samples of hand-picked foraminifers were dated by accelerated mass-spectrometry (Table 2), and the results are shown in Figures $3 B$ and $3 C$, displaying the upper 10 and 5 mbsf of Hole $820 \mathrm{~A}$, respectively. Figure $3 \mathrm{C}$ also shows the isotopic fluctuation for the last $9000 \mathrm{yr}$ plotted vs. independent evidence of sea-level fluctuations for the Great Barrier Reef (Davies and Hopley, 1985; Davies et al., 1985; Mclean et al., 1985). The data in Figures $3 \mathrm{~B}$ and $3 \mathrm{C}$ indicate enriched $\delta^{18} \mathrm{O}$ values that coincided with periods of low sea level and vice-versa. Whether the Holocene $\delta^{18} \mathrm{O}$ values entirely reflect sea-level change or contain a regional temperature overprint is unknown at the present time.

However, on the basis of the data in Figure 3B, we have interpreted the isotope signal into five parts showing (1) a regression from 43,000 to $18,000 \mathrm{yr}$ B.P., (2) a stillstand lasting a very short time, (3) an early transgression before approximately 9400 yr B.P., (4) a late transgression between 9400 and 4900 yr B.P., and (5) a high and/or stillstand from 4900 yr B.P. to present. We propose that this is a glacio-eustatic time framework for sediments deposited during the last glacial perturbation. 
Table 1. Measurements of magnetic susceptibility, the abundance of sand ( $>63 \mu \mathrm{m}$ ) and mud $(<63 \mu \mathrm{m})$, carbonate content in both mud fraction and total sample, and stable oxygen-isotope ratio for $G$. ruber for the upper 35 mbsf of Hole 820A.

\begin{tabular}{|c|c|c|c|c|c|c|c|c|}
\hline \multicolumn{2}{|c|}{ Core, section, interval (cm) } & \multirow{2}{*}{$\begin{array}{l}\begin{array}{l}\text { Depth } \\
\text { (mbsf) }\end{array} \\
0.05\end{array}$} & \multirow{2}{*}{$\begin{array}{l}\begin{array}{l}\text { Susc. } \\
(\mu \mathrm{G} / \mathrm{O} \theta)\end{array} \\
6.252\end{array}$} & \multicolumn{2}{|c|}{$\begin{array}{l}\text { Sand/silt Mud } \\
\begin{array}{ll}(\%) & (\%)\end{array}\end{array}$} & \multirow{2}{*}{$\begin{array}{l}\text { Carb. } \\
\text { total } \\
(\%)\end{array}$} & \multirow{2}{*}{ 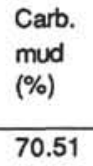 } & \multirow{2}{*}{$\begin{array}{c}\delta^{180}(\mathrm{PDB}) \\
(\%) \\
-2.27\end{array}$} \\
\hline 133-820A- & $1 \mathrm{H}-1,5 \cdot 7$ & & & 84.95 & 15.05 & & & \\
\hline & $1 \mathrm{H} \cdot 1,25-27$ & 0.25 & 5.028 & 85.56 & 14.44 & 71.07 & 69.88 & -2.29 \\
\hline & $1 \mathrm{H}-1,45-47$ & 0.45 & 6.886 & 85.57 & 14.43 & 72.77 & 69.68 & -2.38 \\
\hline & $1 \mathrm{H}-1,65-67$ & 0.65 & 6.135 & 86.00 & 14.00 & 75.31 & 72.27 & -2.42 \\
\hline & $1 \mathrm{H}-1,85-87$ & 0.85 & 5.319 & 81.67 & 18.33 & 68.67 & 64.87 & -2.48 \\
\hline & $1 \mathrm{H}-1,105-107$ & 1.05 & 6.491 & 82.63 & 17.37 & 67.21 & 62.73 & -2.37 \\
\hline & $1 \mathrm{H}-1,125-127$ & 1.25 & 6.650 & 86.27 & 13.73 & 67.01 & 63.54 & -2.32 \\
\hline & $1 \mathrm{H}-1,145-147$ & 1.45 & 5.028 & 85.35 & 14.65 & 65.81 & 62.14 & -2.08 \\
\hline & $1 \mathrm{H}-2,5-7$ & 1.55 & 5.514 & 86.79 & 13.21 & 70.10 & 69.88 & -2.08 \\
\hline & $1 \mathrm{H} \cdot 2,25-27$ & 1.75 & 5.065 & 88.18 & 11.82 & 69.60 & 67.70 & -2.51 \\
\hline & $1 \mathrm{H}-2,45-47$ & 1.95 & 4.742 & 91.22 & 8.78 & 65.40 & 63.23 & -2.59 \\
\hline & $1 \mathrm{H}-2,65-67$ & 2.15 & 3.502 & 83.32 & 16.68 & 64.52 & 59.66 & -2.64 \\
\hline & $1 \mathrm{H}-2,85-87$ & 2.35 & 3.664 & 86.30 & 13.70 & 61.64 & 57.16 & -2.64 \\
\hline & $1 \mathrm{H}-2,93-98$ & 2.43 & & 84.99 & 15.01 & & 58.38 & -2.65 \\
\hline & $1 \mathrm{H}-2,105-107$ & 2.55 & 3.633 & 83.95 & 16.05 & 64.22 & 59.83 & -2.63 \\
\hline & $1 \mathrm{H}-2,125-127$ & 2.75 & 4.552 & 85.75 & 14.25 & 68.39 & 65.03 & -2.40 \\
\hline & $1 \mathrm{H}-2,134-138$ & 2.84 & & 85.05 & 14.95 & & 64.69 & \\
\hline & $1 \mathrm{H}-2,145-147$ & 2.95 & 4.795 & 86.61 & 13.39 & 66.46 & 62.91 & -2.53 \\
\hline & $1 \mathrm{H}-3,5-7$ & 3.05 & 5.284 & 86.43 & 13.57 & 56.88 & 51.44 & -2.54 \\
\hline & $1 \mathrm{H}-3,25-27$ & 3.25 & 5.306 & 84.85 & 15.15 & 56.54 & 50.84 & -2.52 \\
\hline & $1 \mathrm{H}-3,45-47$ & 3.45 & 7.212 & 87.90 & 12.10 & 56.12 & 53.07 & -2.27 \\
\hline & $1 \mathrm{H}-3,53-58$ & 3.53 & & 81.06 & 18.94 & & 58.14 & \\
\hline & $1 \mathrm{H}-3,65-67$ & 3.65 & 9.925 & 89.37 & 10.63 & 57.08 & 55.33 & -2.18 \\
\hline & $1 \mathrm{H}-3,85-87$ & 3.85 & 10.542 & 86.79 & 13.21 & 54.84 & 50.73 & -2.18 \\
\hline & $1 \mathrm{H}-3,93-98$ & 3.93 & & 87.68 & 12.32 & & 54.29 & -2.18 \\
\hline & $1 \mathrm{H}-3,105-107$ & 4.05 & 9.439 & 86.12 & 13.88 & 53.87 & & -2.41 \\
\hline & $1 \mathrm{H}-3,114-118$ & 4.14 & & 87.35 & 12.65 & & 47.42 & \\
\hline & $1 \mathrm{H}-3,125-127$ & 4.25 & 13.086 & 88.64 & 11.36 & 48.70 & 42.64 & -2.42 \\
\hline & $1 \mathrm{H}-3,145-147$ & 4.45 & 12.708 & 90.06 & 9.94 & 43.96 & 39.45 & -1.94 \\
\hline & $1 \mathrm{H}-4,5-7$ & 4.55 & 10.533 & 91.63 & 8.37 & 46.72 & 42.85 & -1.99 \\
\hline & $1 \mathrm{H}-4,25-27$ & 4.75 & 9.670 & 86.04 & 13.96 & 47.84 & 40.65 & -2.03 \\
\hline & $1 \mathrm{H}-4,45-47$ & 4.95 & 13.179 & 89.04 & 10.96 & 41.54 & 35.93 & -2.17 \\
\hline & $1 \mathrm{H}-4,65-67$ & 5.15 & 14.844 & 89.62 & 10.38 & 41.13 & 31.53 & -2.20 \\
\hline & $1 \mathrm{H}-4,85-87$ & 5.35 & 14.069 & 89.80 & 10.20 & 41.41 & 38.55 & -2.19 \\
\hline & $1 \mathrm{H} \cdot 4,105-107$ & 5.55 & 15.226 & 94.44 & 5.56 & 39.10 & 37.09 & -2.15 \\
\hline & $1 \mathrm{H}-4,114-118$ & 5.64 & & 93.72 & 6.28 & & 37.60 & \\
\hline & $1 \mathrm{H}-4,125-127$ & 5.75 & 13.891 & 92.89 & 7.11 & 38.90 & 35.42 & -2.13 \\
\hline & $1 \mathrm{H}-4,145-147$ & 5.95 & 14.800 & 93.48 & 6.52 & 31.40 & 27.59 & -1.97 \\
\hline & $1 \mathrm{H}-5,5-7$ & 6.05 & 12.619 & 91.40 & 8.60 & 41.05 & 36.66 & -2.22 \\
\hline & $1 \mathrm{H}-5,25-27$ & 6.25 & 15.905 & 90.34 & 9.66 & 44.41 & 39.51 & -1.77 \\
\hline & $1 \mathrm{H}-5,45-47$ & 6.45 & 22.373 & 90.50 & 9.50 & 35.31 & 29.90 & -1.81 \\
\hline & $1 \mathrm{H}-5,65-67$ & 6.65 & 23.168 & 82.21 & 17.79 & 50.21 & 45.91 & -1.82 \\
\hline & $1 \mathrm{H}-5,85-87$ & 6.85 & 32.443 & 78.40 & 21.60 & 48.07 & 39.96 & -1.62 \\
\hline & $1 \mathrm{H}-5,93-98$ & 6.93 & & 79.53 & 20.47 & & 39.31 & -1.68 \\
\hline & $2 \mathrm{H}-1,5-7$ & 7.25 & 10.962 & 39.67 & 60.33 & 78.40 & 61.47 & -0.98 \\
\hline & $2 \mathrm{H}-1,25-27$ & 7.45 & 5.509 & 41.06 & 58.94 & 76.80 & 65.22 & -1.37 \\
\hline & $2 \mathrm{H}-1,45-47$ & 7.65 & 2.931 & 46.89 & 53.11 & 82.67 & 70.98 & -1.44 \\
\hline & $2 \mathrm{H}-1,65-67$ & 7.85 & 4.187 & 60.44 & 39.56 & 87.02 & 76.32 & -1.61 \\
\hline & $2 \mathrm{H}-1,72-77$ & 7.92 & & 61.76 & 38.24 & & 76.93 & -1.65 \\
\hline & $2 \mathrm{H}-1,85-87$ & 8.05 & 2.091 & 76.34 & 23.66 & 67.03 & 61.10 & -1.86 \\
\hline & $2 \mathrm{H}-1,105-107$ & 8.25 & 2.294 & 79.70 & 20.30 & 61.42 & 54.82 & -1.79 \\
\hline & $2 \mathrm{H}-1,125-127$ & 8.45 & 4.693 & 81.64 & 18.36 & 63.38 & 62.67 & -1.74 \\
\hline & $2 \mathrm{H}-2,5-7$ & 8.75 & 3.323 & 74.42 & 25.58 & 64.64 & 61.10 & -1.78 \\
\hline & $2 \mathrm{H}-2,25-27$ & 8.95 & 3.015 & 75.47 & 24.53 & & 64.62 & -1.69 \\
\hline & $2 \mathrm{H}-2,45-47$ & 9.15 & 3.308 & 75.19 & 24.81 & 60.49 & 57.09 & -1.67 \\
\hline & $2 \mathrm{H}-2,65-67$ & 9.35 & 4.224 & 75.44 & 24.56 & 57.17 & & -1.76 \\
\hline & $2 \mathrm{H}-2,85-87$ & 9.55 & 3.920 & 79.14 & 20.86 & 61.14 & 56.01 & -1.78 \\
\hline & $2 \mathrm{H}-2,105-107$ & 9.75 & 4.959 & 83.36 & 16.64 & 57.19 & 51.43 & -1.75 \\
\hline & $2 \mathrm{H}-2,125-127$ & 9.95 & 5.328 & 88.95 & 11.05 & & 41.01 & -1.60 \\
\hline & $2 \mathrm{H}-2,145-147$ & 10.15 & 4.906 & 87.47 & 12.53 & 45.07 & 37.07 & -1.57 \\
\hline
\end{tabular}


A Depth (mbsf)

B

Dẹth (mbsf)

C

Depth (mbsf)

$\begin{array}{llllllll}0 & 5 & 10 & 15 & 20 & 25 & 30 & 35\end{array}$

$\begin{array}{lllllllllll}0 & 1 & 2 & 3 & 4 & 5 & 6 & 7 & 8 & 9 & 10\end{array}$

$\begin{array}{llllll}0.0 & 1.0 & 2.0 & 3.0 & 4.0 & 5.0\end{array}$
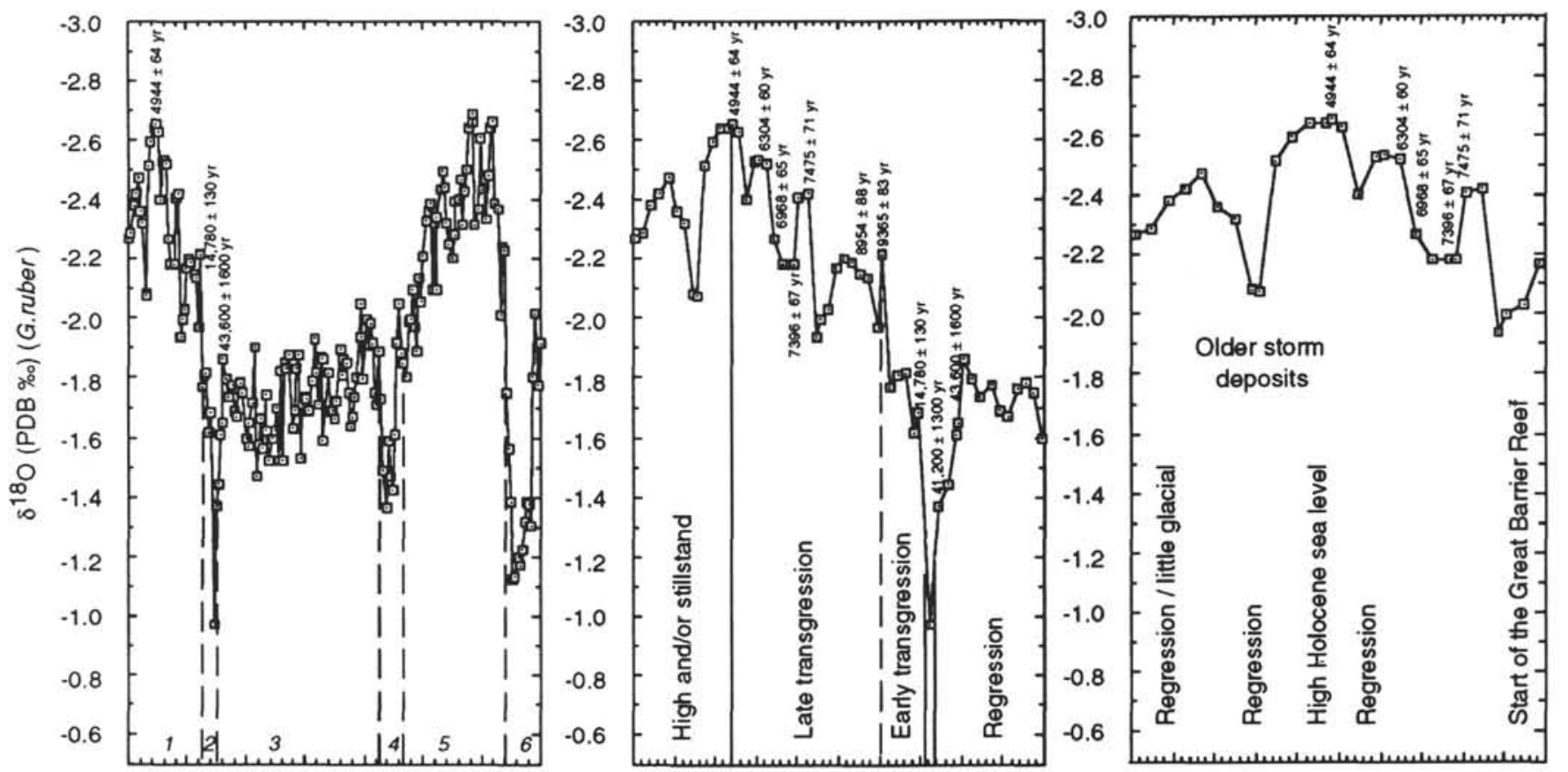

Figure 3. Stable oxygen-isotope ratios of G. ruber for the upper $35 \mathrm{mbsf}(\mathbf{A}), 10 \mathrm{mbsf}(\mathbf{B})$, and $5 \mathrm{mbsf}$ (C). Interpretation of sea-level-related deposits is supported by 10 AMS radiocarbon dates. Independent data (C), indicating climatic and sea-level changes, are from Davies et al. (1985), Davies and Hopley (1983), and Mclean et al. (1985). The numbers in the left diagram represent successive oxygen-isotope stages.

Table 2. AMS radiocarbon dates for 10 samples in the upper $10 \mathrm{mbsf}$ of Hole 820A.

$\begin{array}{ll}\text { Core, section, interval (cm) } & \begin{array}{l}\text { Depth }{ }^{14} \mathrm{C} \text { age } \\ \text { (mbsf) (yr B.P.) }\end{array}\end{array}$

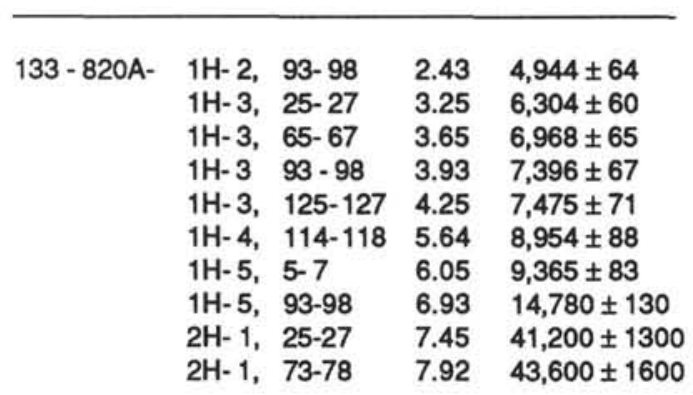

The distribution of sand, mud, calcium carbonate of the mud fraction and total sample, and magnetic susceptibility are shown in Figures 4 and 5. Both diagrams also show the positions of the regression, lowstand, early and late transgressions, and highstand of sea level. We find the following from these data.

The regression is characterized by a coarse bioclastic wackestone/packstone with a significant increase in the abundance of sand from $15 \%$ during the early regression to approximately $60 \%$ at the beginning of the sea-level lowstand. Microscopic analysis, shown in Figure $6 \mathrm{~A}$, indicates that where the abundances of sand are high, the sand fraction mainly comprises bioclasts such as planktonic and benthic foraminifers, mollusks, gastropods, and pteropod fragments that occasionally are pyritized. The abundance of mud, as a residual to the sand fraction, decreases from $85 \%$ to $40 \%$. The carbonate content of the mud fraction is typically $85 \%$ and $75 \%$ of the total sample, slightly decreasing toward the lowstand in sea level. Magnetic susceptibilty rapidly increases at the end of the regression from values of around 3 to $15 \mathrm{mG} \mathrm{Oe}^{-1}$.

The lowstand, containing a coarse bioclastic packstone (Fig. 6B), displays highest and lowest abundances of sand and mud fractions, respectively, with approximately $60 \%$ sand and $40 \%$ mud, and carbonate content of both mud fraction and total sample slightly decreasing to values of around $65 \%$ and $80 \%$. Bioclasts are similar to those deposited during the regression, but contain additional fragments of coralline algae, bryozoan fragments, rhodoliths, and nonskeletal carbonated particles. Magnetic susceptibility remains around $15 \mu \mathrm{G} \mathrm{Oe}^{-1}$.

The early transgression, with organic-rich, fine bioclastic wackestones (Fig. 6C), shows a marked increase in the mud fraction from around $45 \%$ to values of more than $90 \%$, with a corresponding decrease in the sand to less than $10 \%$. Major noncarbonate mineral phases in the mud fraction are muscovite, quartz, kaolinite, and hematite. Bioclasts mainly consist of planktonic foraminifers and pteropod fragments. This early transgression also shows a marked decrease of carbonate content from $80 \%$ to $30 \%$ for the mud and from $90 \%$ to $30 \%$ for the total sample. Magnetic susceptibility is highest at the beginning of the early transgression and decreases throughout the rest of the early transgression, with values ranging from 45 to $10 \mu \mathrm{G} \mathrm{Oe}^{-1}$.

The late transgression, comprising fine bioclastic wackestones, is characterized by sand percentages of between $5 \%$ and $20 \%$ and mud percentages between $80 \%$ and $95 \%$. Again, bioclasts contain planktonic foraminifers, as well as pteropod and coral fragments (Fig. 6D). Note that the abundances of sand progressively increase toward the end of the late transgression. Carbonate percentages slowly increase throughout the late transgression to values of $65 \%$ for both the mud 
B Calcium carbonate percentage of $<63 \mu \mathrm{m}$ fraction and total sample

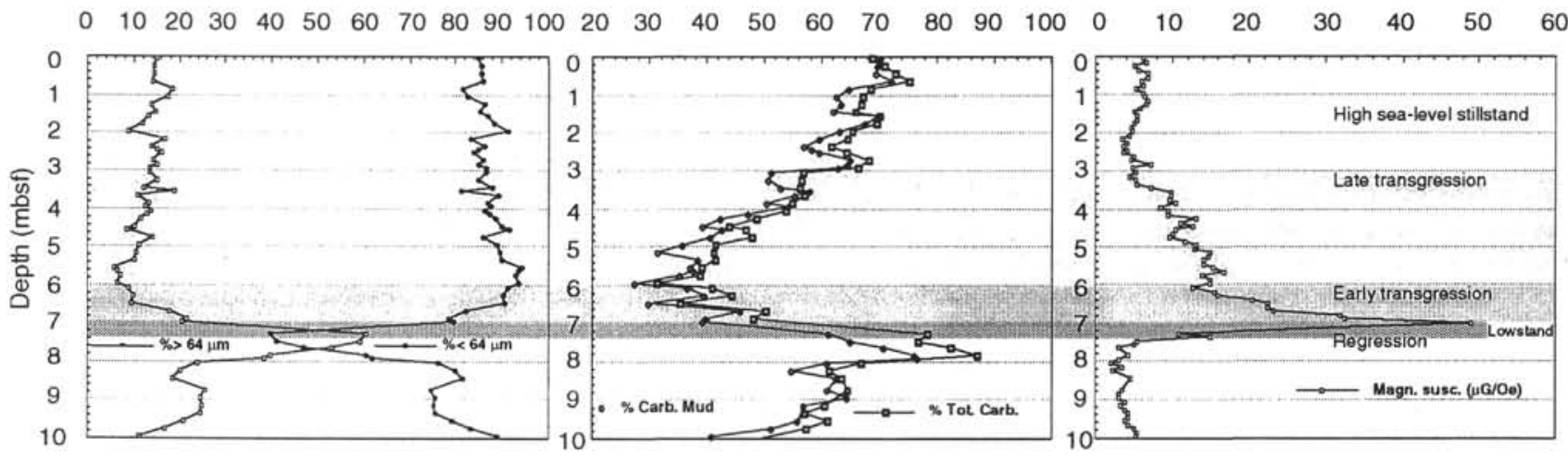

Figure 4. Correlation between lithostratigraphic development and established glacio-eustatic and time framework for the upper $10 \mathrm{mbsf}$ of Hole $820 \mathrm{~A}$. The shaded areas represent sea-level-related packages of sediments, as defined in Figure 3.

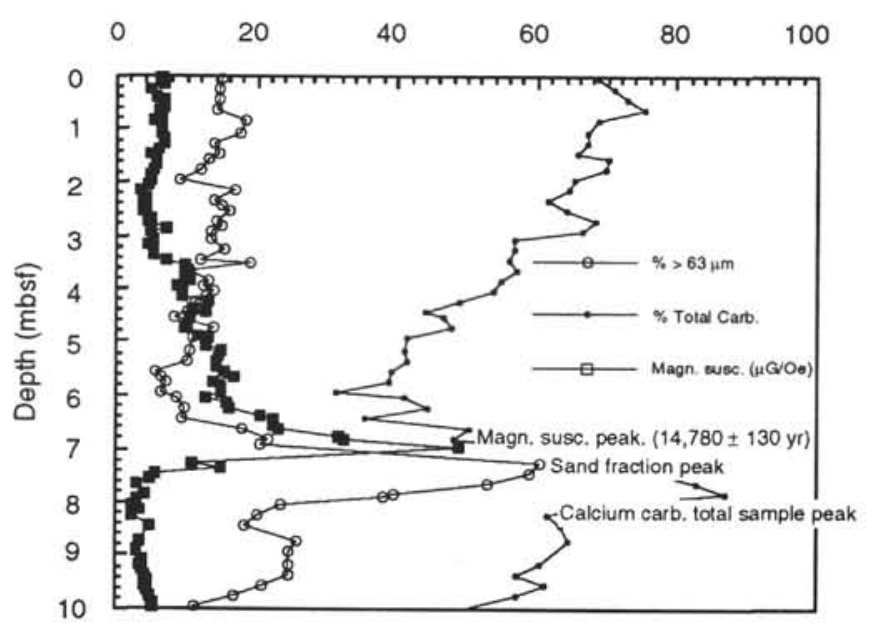

Figure 5. Downhole fluctuations of calcium carbonate content for the total sample, the larger than $63-\mu \mathrm{m}$ fraction, and magnetic susceptibility show a distinct offset of peaks of the three parameters during the last glacial perturbation.

fraction and the total sample. In spite of this, magnetic susceptibility values decrease to approximately $3 \mu \mathrm{G} \mathrm{Oe}^{-1}$.

The Holocene highstand/stillstand embraces (1) a fine bioclastic wackestone, with sand and mud abundances similar to those of the late transgression, (2) an increase of carbonate content to $65 \%$ to $70 \%$ in both the mud fraction and total sample, and (3) a small increase in magnetic susceptibility to around $6 \mu \mathrm{G} \mathrm{Oe}^{-1}$. The composition of the bioclasts is similar to those of the late transgression.

Clearly, relationships exist between the studied sedimentary parameters and changes in glacio-eustatic sea level. However, the peak of the regression at a depth of about $7 \mathrm{~m}$ (Fig. 5) indicates a lag, with the regression seen first in the carbonate peak, followed by the sand fraction, and finally, by the susceptibility peak.

\section{DISCUSSION}

Comprehensive studies of the textural and compositional characteristics of carbonate-dominated shelf and slope sediments have already been performed on the continental margins of, for instance, the eastern Gulf of Mexico and the Bahamas. These studies have focused on the signature of Pleistocene sea-level lowstands and highstands, seen in slope sediments of mixed carbonate-siliciclastic systems having carbonate ramps (Gardulski et al., 1986; Roof et al., 1991) and carbonate-dominated margins having rimmed platforms (Kier and Pilkey, 1971; Boardman and Neumann, 1984; Boardman et al., 1986; Droxler et al., 1983). These studies have shown (1) that textural and compositional variation of periplatform sediments encapsulate a history of response of carbonate bank-tops to fluctuations in sea level (Boardman and Neumann, 1984; Boardman et al., 1986), although others have demonstrated the importance of variable surface productivity (Gardulski et al., 1986) and dissolution of the unstable aragonite phase (Droxler, 1985) in the deduction of sea level from periplatform deposits, and (2) that the recognition of the depositional environment (rimmed platform or ramp attached to a continent) is critical for interpreting cyclic slope sedimentation and is the key to the study of ancient cyclic carbonate sequences (Gardulski et al., 1986).

The Great Barrier Reef is $2000 \mathrm{~km}$ long. The physical and chemical conditions existing along its margin are diverse (Maxwell and Swinchatt, 1970). Sites 819 to 821 were drilled in a location where the Great Barrier Reef changes from dominantly rimmed in the north to a ramp-shaped continental margin in the south. As a result, it represents a model, different from anything described for the Bahamas and the eastern Gulf of Mexico. We propose therefore that our results will define one of a number of models for mixed carbonate-siliciclastic margins. We intend to discuss this in terms of its coherent parts.

In the Great Barrier Reef, a rapid, glacially induced eustatic oscillation defines the sequence, shown schematically in Figure 7.

\section{The Regression and Lowstand}

The stratigraphic and sedimentologic response of a fall in sea level shows the development of a condensed sequence at the base that formed during the regression, with sedimentation rates of around 2.8 $\mathrm{cm} / \mathrm{k}$.y. The condensed sequence is characterized by (1) an increase in the abundance of sand, with planktonic and benthic foraminifers as the principal bioclastic constituent, (2) highest abundances of carbonate content in both the mud fraction and the total sample, up to $80 \%$ to $90 \%$, and (3) generally, low magnetic susceptibility values. Lowstand sedimentation is characterized by the highest abundances of sand $(60 \%)$, made up of abundant planktonic and benthic foraminifers, but also containing coralline algae, bryozoan fragments, rhodoliths, and lithoclasts. In addition, lowstand sedimentation is expressed by an increase in magnetic susceptibility and a decrease in carbonate content of both the mud fraction and the total sample. 

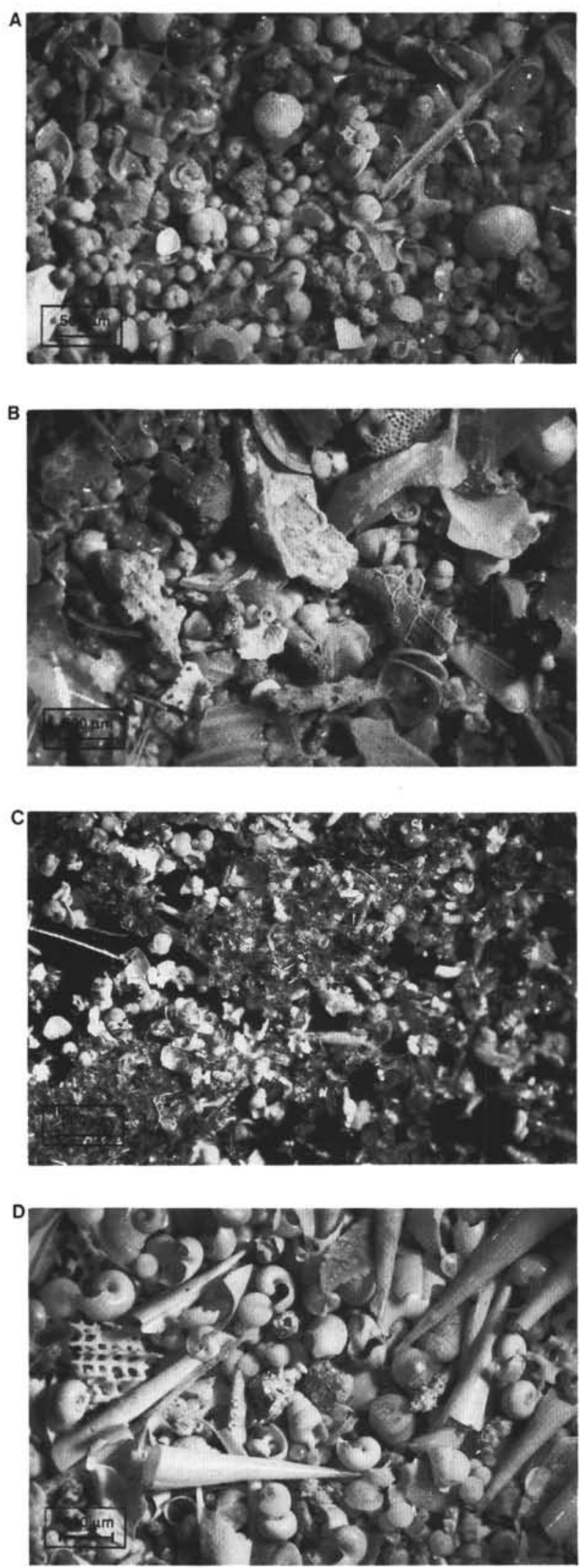

Figure 6. Photographs showing representative sand fraction $(63 \mu \mathrm{m})$ for $(\mathbf{A})$ the regression, (B) the lowstand, (C), the early transgression, and (D) the late transgression. Photographs from the regression and lowstand show sediments rich in skeletal carbonate grains, with abundant planktonic and benthic foraminifers. In addition, lowstand sediments contain fragments of coralline algae, bryozoan fragments, and rhodoliths. The photographs of the early and late transgressions also display bioclastic sediments, with abundant foramini-fers, pteropods, and coral fragments. Note the organic contribution in (C).
The formation of lowstand condensed sequences has been reported in the Bahamas, where Lynts et al. (1973) and Droxler and Schlager (1985) showed low sea-level sedimentation rates, four to six times lower than those at high sea level. Such rates are explained by exposure of the platform during the period of relative decrease in sea level that caused platform production and shedding to cease (Kier and Pilkey, 1971; Sarg, 1988). This is different from mixed carbonatesiliciclastic systems in the eastern Gulf of Mexico, where regression and lowstand deposits are reported to reflect the influx of terrigenous mud from the continent during periods of low sea level, thus diluting the pelagic components and reducing relative sand concentration (Gardulski et al., 1986; Roof et al., 1991). Our data show no evidence for dilution; on the contrary, the percentage of carbonate-rich sand increases throughout the regression to maximum values during the lowstand, with a high carbonate peak pre-dating the sea-level lowstand. The sediments lack mud and terrigenous sand. We think that the small amounts of carbonate mud that were deposited during the regression and lowstand result from a decrease in carbonate production. Whether this can be entirely related to the cessation of platform growth or also to changes in sea-surface productivity is unclear. We postulate that terrigenous sand-sized sediments bypassed the outer shelf, allowing for the physical separation in the water column necessary to explain the occurrence of small amounts of terrigenous mud. Excavated shelf river channels on the outer shelf are identified and described by Feary (this volume) and possibly indicate such a sedimentary system.

\section{The Early Transgression}

The early transgression is characterized by (1) an increase in sedimentation rates up to $22.2 \mathrm{~cm} / \mathrm{k} . \mathrm{y}$; (2) highest magnetic susceptibility values at its beginning but rapidly decreasing toward the end; (3) a drastic change in grain size and carbonate content at the transition from lowstand to early transgression, with the abundance of sand decreasing by $50 \%$ and carbonate content decreasing by $45 \%$; (4) sand- sized constituents only containing planktonic and benthic foraminifers and fragments of pteropods; (5) an increase in the abundance of terrigenous components of the mud fraction with terrigenous clays, quartz, and hematite as dominant mineralogical phases; (6) a stable, single-domain remanence with a significant contribution from ultrafine, superparamagnetic grains, defined by Barton et al. (this volume) as marking the sharp peak of maximum susceptibility just after the lowstand in sea level (heaviest $\delta^{18} \mathrm{O}$ value) and interpreted to define the derivation from either the continent or the exposed platform; and (7) minor abundances of aragonite having a $\mathrm{Ar} / \mathrm{Ca}$ ratio of 0.25 and defining the early transgression, but increasing to approximately 0.55 during the late transgression. A similar carbonate trend also is seen in the sediments of the eastern Gulf of Mexico (Gardulski et al., 1986) and has been attributed to pelagic-driven sedimentation during glacial periods, switiching over to platform-driven during interglacial periods. This is different from the process-response in the Bahamas, where variations in concentration of aragonite have been explained as climatic related dissolution (Droxler et al., 1983). Nevertheless, off the northeastern Australian margin, the rapid decrease in the abundance of the sand fraction and the high noncarbonate component, seen at Hole $820 \mathrm{~A}$, are different from the scenarios described for the eastern Gulf of Mexico and the Bahamas. We ascribe these textural and compositional changes to dilution of pelagic sediments by finegrained terrigenous mud, commonly seen during a sea-level lowstand in mixed carbonate-siliciclastic systems.

\section{The Late Transgression}

The late transgression is characterized by (1) highest sedimentation rates of $82.3 \mathrm{~cm} / \mathrm{k} . y$. ., (2) little variation in grain size, (3) a gradual increase in carbonate content, (4) a gradual decrease in magnetic 


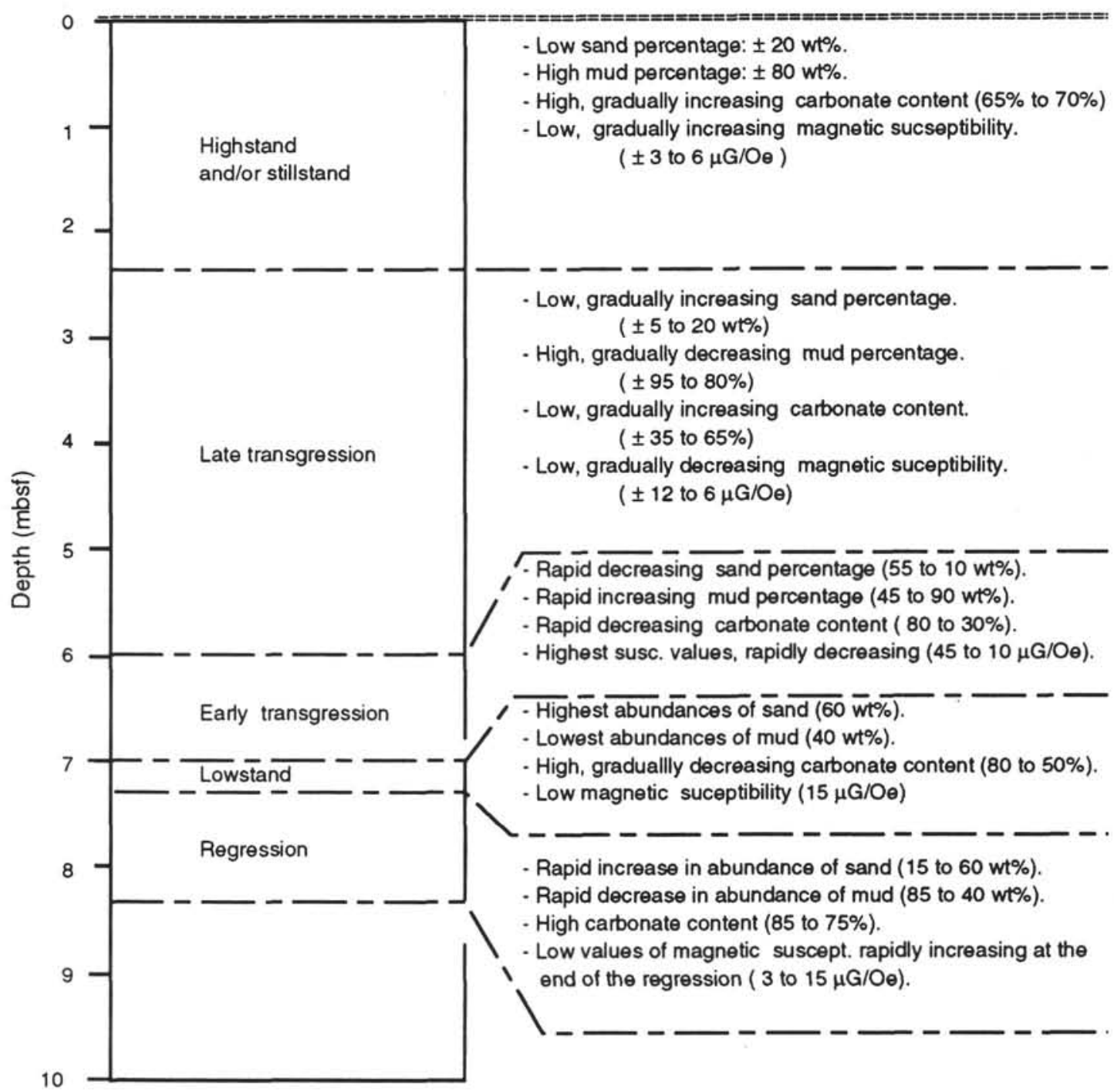

Figure 7. Schematic diagram of stratigraphy and sedimentology of a sequence, resulting from a rapid glacial-induced eustatic oscillation.

susceptibility, and (5) a sediment texture similar to that during the early transgression; planktonic and benthic foraminifers are the major sand constituents, together with pteropod fragments; occasionally, coral fragments can be found.

Compositional differences compared with the early transgression are pronounced. The terrigenous component of the mud fraction decreases from $70 \%$ to $40 \%$, and magnetic susceptibility values are four times smaller than the maximum value at the beginning of the early transgression. These variations, along with the highest sedimentation rates, appear to occur roughly at a time when the Holocene Great Barrier Reef started to grow (Davies et al., 1985) and when the shoreline would have been at $-20 \mathrm{~m}$ in the inner shelf. Thus, muds were restricted to coastal sinks, while carbonate was being produced. Dating of reef cores suggests that Holocene reef growth was initiated at about 8500 y.r. B.P. (Davies et al., 1985). A comparable situation is seen in the Bahamas and the eastern Gulf of Mexico, where increased sedimentation rates are also related to initiation of reef growth (Boardman and Neumann, 1984).

The observations described above contradict the sequence stratigraphic models developed by Vail et al. (1977) that propose that condensed sequences on continental slopes formed during transgression and highest rates of sedimentation occurred during lowstands of sea level. Our data clearly suggest the opposite for mixed carbonatesiliciclastic margins of the type drilled in the Great Barrier Reef.

\section{The Highstand}

The sediments developed in the Holocene stillstand, which off the northeastern Australian margin lasted for $6000 \mathrm{yr}$, show no significant changes in either texture or composition. Magnetic susceptibility, grain size, and carbonate content remain effectively constant throughout the stillstand. Sedimentation rates, however, are lower than those in the late transgression. The initiation of filling the middleshelf inter-reef areas of the Great Barrier Reef has been recognized by Harris et al. (1990) to have occurred at about 4 to 6 k.y. B.P., which roughly coincides with a decrease in sedimentation rate on the outer shelf, possibly indicating an autocyclic response of the Great Barrier Reef to the Holocene highstand.

Using the above interpretations, we extend our conclusions to an interpretation of sea-level oscillations seen in the core throughout the first $35 \mathrm{mbsf}$, which represents the last $130,000 \mathrm{yr}$. Barton et al. (this volume) and Feary and Jarrard (this volume) show that at least for the first 65 mbsf of Hole $820 \mathrm{~A}$, textural and compositional variations respond in a similar way to fluctuations in sea level. 


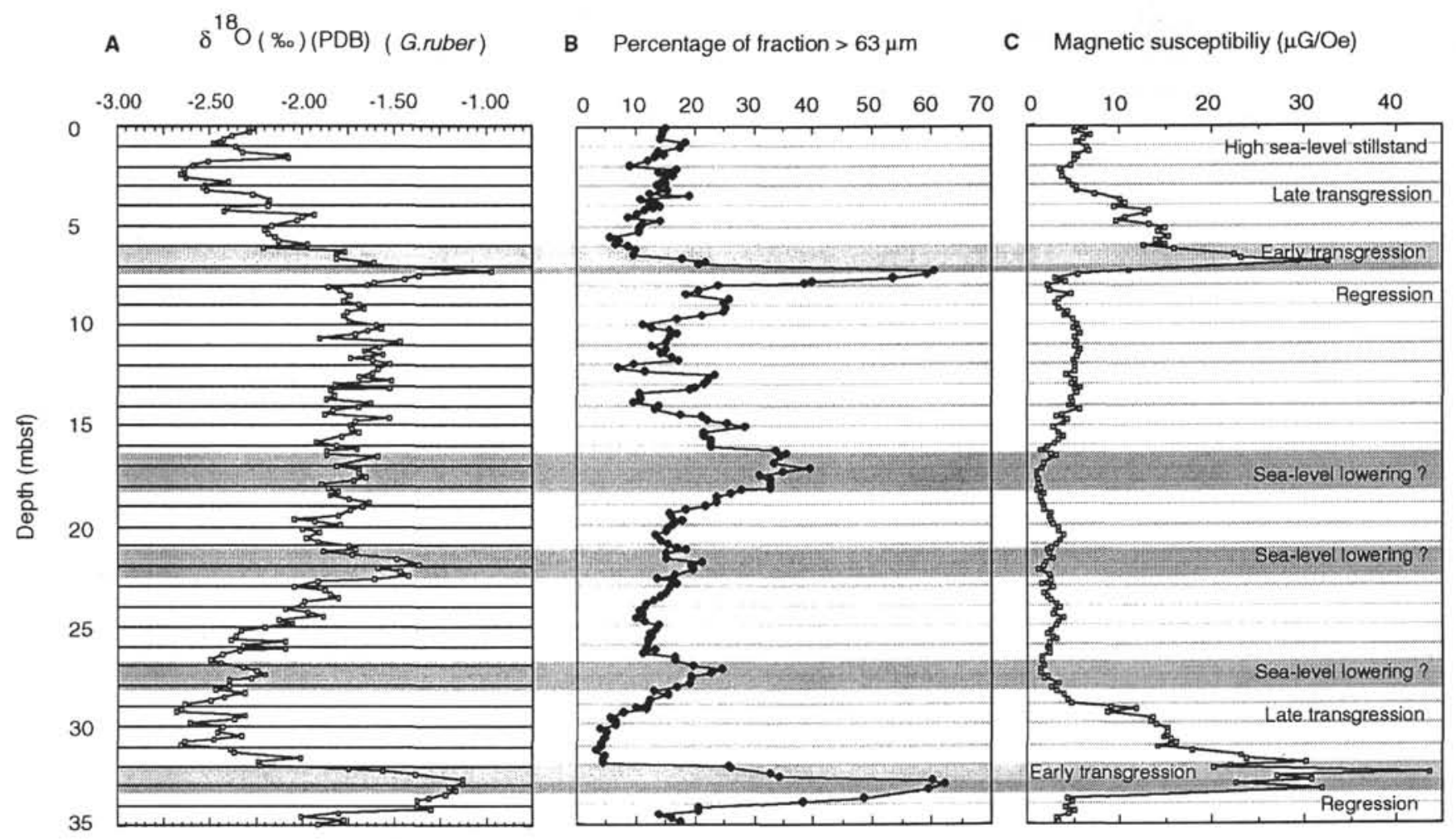

Figure 8. Interpretation of sea-level-related deposits for the upper $35 \mathrm{mbsf}$ of Hole $820 \mathrm{~A}$, based on oxygen-isotope stratigraphy, sand fraction variations, and magnetic susceptibility.

Oxygen-isotopic, percentage of sand, and susceptibility variations are shown in Figure 8. In this figure, one can clearly see that the heaviest values of $\delta^{18} \mathrm{O}$, interpreted as glacial stage 6 , correlate with a coarse bioclastic packstone having high percentages of sand and high values of magnetic susceptibility. Bioclast constituents, again, are abundant foraminifers, rhodoliths, coralline algae, bryozoan fragments, and lithoclasts. Even in the absence of detailed carbonate data, we think that we can recognize a regression in sediments up to $34 \mathrm{mbsf}$, a lowstand at $34 \mathrm{mbsf}$, an early transgression from 34 to $33 \mathrm{mbsf}$, and a late transgression from 33 to $29.25 \mathrm{mbsf}$, similar to that of the last sea-level oscillation. Process and process-response are similar over two major glacial perturbations. However, the interval between the two major lowstands (stages 2 and 6 ) is more difficult to interpret. Few variations in magnetic susceptibility can be seen in this interval. Barton et al. (this volume) ascribe these variations as having been effected by calcium carbonate dilution and thus reflect fluctuations in calcium carbonate. However, significant variations in both isotopes and the percentage of sand in this interval exist that show little correlation. In an attempt to interpret these variations, we have accompanied both signals with an independent estimate of sea level for the last $130,000 \mathrm{yr}$ that was published by Shackleton (1987; Fig. 9). Pattern matching suggests that isotope stages $3,4,5 \mathrm{a}$ through $5 \mathrm{~d}$, and $5 \mathrm{e}$ are present and, in particular, are clearly seen in the distribution of the percentage of sand. However, we propose caution when over-interpreting these data because the sand fraction for this interval mainly consists of planktonic foraminifers and pteropod fragments, and variations in the abundance of sand may therefore reflect (1) variable surface productivity, (2) shedding of the platform (whether or not controlled by sea level through dilution by lime mud), and (3) dissolution of the aragonite in the mud fraction.

\section{CONCLUSIONS}

1. In using a detailed age model from radiocarbon ages, correlated with stable oxygen isotope data, we have defined in the upper $8 \mathrm{mbsf}$ of Hole $820 \mathrm{~A}$ the position of a sea-level regression $(41,000-18,000$ yr B.P.), a lowstand, early ( $18,000-9400$ yr B.P.) and late ( $9400-4900$ $\mathrm{yr}$ B.P.) transgressions, and a highstand ( $4900 \mathrm{yr}$ to the present).

2. Each part of the sea-level oscillation can be correlated with a unique combination of textural and compositional characteristics. These characteristics are summarized in Table 3. Four important points can be summarized as follows:

A. A condensed sequence develops during the regression. A fall in sea level produces a coarse bioclastic wackestone/packstone with a rapid increase in both sand-sized and carbonate components that mainly comprise planktonic and benthic foraminifers. A sea-level lowstand results in a highly calcareous bioclastic packstone having maximum abundances of sand that comprises abundant planktonic and benthic foraminifers, but also rhodoliths, bryozoan fragments, coralline algae, and lithoclasts. Sand-sized terrigenous sediments are proposed to have bypassed the continental shelf during sea-level lowstand. Sedimentation rates are low $(3.0 \mathrm{~cm} / \mathrm{k} . \mathrm{y}$.) throughout the regression and lowstand.

B. The early transgressive sequence is thin and contains a fine, bioclastic (foraminifers and pteropod fragments) wackestone having a low percentage of sand and a substantial terrigenous-mud component. Magnetic susceptibility values are high. Low percentages of sand and increased sedimentation rates reflect dilution of pelagic sediments by terrigenous mud.

C. Sedimentation rates are highest and the sequence is thickest in the late transgression. This roughly coincides with the initiation of the Great Barrier Reef at 8500 k.y. B.P. A decrease in noncarbonate constituents in the mud fraction during the late transgression and sea-level highstand is thought to be the result of restricted inner-shelf sedimentation of terrigenous sediments.

D. Rates are less in the highstand than in the late transgression.

3. By extending our interpretation of the last sea-level oscillation to the upper $35 \mathrm{~m}$ of Hole $820 \mathrm{~A}$, we conclude that process and process-response are similar over the last two major glacial perturbations. 


\section{ACKNOWLEDGMENTS}

The assistance of Joe Cali at the Research School of Earth Sciences, Australian National University, and Paul Attenborough at BMR's Marine Sedimentology Laboratory is gratefully acknowledged.

\section{REFERENCES}

Boardman, M.R., and Neumann, A.C., 1984. Sources of periplatform carbonates: Northwest Providence Channel, Bahamas. J. Sediment. Petrol., 54:1110-1123.

Boardman, M.R., Neumann, A.C., Baker, P.A., Dulin, L.A., Kenter, R.J., Hunter, G.E., and Kiefer, K.B., 1986. Banktop response to Quaternary fluctuations in sea level recorded in periplatform sediments. Geology, 14:28-31.

Davies, P.J., and Hopley, D., 1983. Growth fabrics and growth rates of Holocene reefs in the Great Barrier Reef. BMR J. Aust. Geol. Geophys., $8: 237-251$.

Davies, P.J., Marshall, J., and Hopley, D., 1985. Relationships between reef growth and sea level in the Great Barrier Reef. Proc. 5th Int. Coral Reef Congr., Tahiti, 3:95-104.

Davies, P.J., McKenzie, J.A., and Palmer-Julson, A., et al., 1991. Proc. ODP, Init. Repts., 133: College Station, TX (Ocean Drilling Program).

Droxler, A.W., 1985. Last Deglaciation in the Bahamian basins and the adjacent Atlantic Ocean. A dissolution record from variations of aragonite content. In Sundquist, E.T., and Broecker, W.S. (Eds.), The Carbonate Cycle and Atmospheric $\mathrm{CO}_{2}$ : Natural Variations, Archean to Present. Am. Geophys. Union Monogr., 32:195-207.

Droxler, A.W., and Schlager, W., 1985. Glacial versus interglacial sedimentation rates and turbidite frequency in the Bahamas. Geology, 13:799-802.

Droxler, A.W., Schlager, W., and Whallon, C.C., 1983. Quaternary aragonite cycles and oxygen-isotope record in Bahamian carbonate ooze. Geology, 11:235-239.

Epstein, S., Buchsbaum, S.R., Lowenstam, H.A., and Urey, H., 1953. Revised carbonate-water isotopic temperature scale. Geol. Soc. Am. Bull., 64:1315-1326.

Feary, D.A., Pigram, C.J., Davies, P.J., Symonds, P.A., Droxler, A.W., and Peerdeman, F.M., 1990. Ocean Drilling Program Project-Leg 133 safety package. Bur: Miner: Res. Rec., 1990/6:1-72.
Gardulski, A.F., Mullins, H.T., and Oldfield, B., 1986. Carbonate mineral cycles in ramp slope sediment: eastern Gulf of Mexico. Paleoceanography, 4:555-565.

Harris, P.T., Davies, P.J., and Marshall, J.F., 1990. Late Quaternary sedimentation on the Great Barrier Reef continental shelf and slope east of Townsville, Australia. Mar. Geol., 94:55-77.

Kier, J.S., and Pilkey, O.H., 1971. The influence of sea level changes on sediment carbonate mineralogy, Tongue of the Ocean, Bahamas. Mar. Geol., 11:189-200.

Lynts, G.W., Judd, J.B., and Stehman, C.F., 1973. Late Pleistocene History of Tongue of the Ocean, Bahamas. Geol. Soc. Am. Bull., 84:2665-2684.

Maxwell, W.G.H., and Swinchatt, J.P., 1970. Great Barrier Reef: regional variation in a terrigenous-carbonate province. Geol. Soc. Am. Bull., 81:691-724.

McLean, R.F., Stoddart, D.R., Hopley, D., and Polach, H., 1978. Sea level change in the Holocene on the northern Great Barrier Reef. Philos. Trans. R. Soc. London A, 291:167-186.

Roof, S.R., Mullins, H.T., Gartner, S., Huang, T.C., Joyce, E., Prutzman, J., and Tjalsma, L., 1991. Climatic forcing of cyclic carbonate sedimentation during the last 5.4 million years along the west Florida continental margin. J. Sediment. Petrol., 61:1070-1088.

Sarg, J.F., 1988. Carbonate sequence stratigraphy. In Wilgus, C.K., Posamentier, H., Van Wagoner, J., Ross, C.A., and Kendall, G.St.C.C. (Eds.), Sea-level Changes: An Integrated Approach. Spec. Publ., Soc. Econ. Paleontol. Mineral., 42:155-181.

Shackleton, N.J., 1987. Oxygen isotopes, ice volume, and sea level. Quat. Sci. Rev., 6:183-190.

Vail, P.R., Mitchum, R.M., Jr., Todd, R.G., Widmier, J.M., Thompson, S., III, Sangree, J.B., Bubb, J.N. and Hatlelid, W.G., 1977. In Payton, C.E. (Ed.), Seismic Stratigraphy-Applications to Hydrocarbon Exploration. AAPG Mem., 26:49-212.

\footnotetext{
Abbreviations for names of organizations and publications in ODP reference lists follow the style given in Chemical Abstracts Service Source Index (published by American
} Chemical Society).

Date of initial receipt: 13 April 1992

Date of acceptance: 9 September 1992

Ms 133SR-236

Table 3. Stratigraphic and sedimentological development during the last glacial perturbation.

\section{Period Time Sed. rate Sediment Sand Mud Mud Mud Total Texture (k.y.) (cm/k.y.) Thickeness (\%) (\%) Terrig $\mathrm{CaCO}_{3} \mathrm{CaCO}_{3}$}

(m)

(\%) (\%)

(\%)

\begin{tabular}{|c|c|c|c|c|c|c|c|c|c|}
\hline Regression & 30 & 3.0 & 0.9 & $20-60$ & $40-80$ & $20-45$ & $55-80$ & $60-90$ & $\begin{array}{l}\text { Coarse bioclastic wackestone/ packstone } \\
\text { (foraminifers and pteropod fragments) }\end{array}$ \\
\hline Lowstand & $<0.5$ & $?$ & $<0.2$ & 60 & 40 & 40 & 60 & 80 & $\begin{array}{l}\text { Coarse bioclastic packstone } \\
\text { (foraminifers, rhodoliths, bryozoan fragm. } \\
\text { lithoclasts, corraline algae) }\end{array}$ \\
\hline $\begin{array}{l}\text { Early } \\
\text { Transgressio: }\end{array}$ & on & 22.2 & 1.2 & $5-60$ & $40-95$ & $60-70$ & $30-40$ & $35-50$ & $\begin{array}{l}\text { Fine bioclastic wackestone (terrigenous-mud } \\
\text { foraminifers and pteropod fragments) }\end{array}$ \\
\hline $\begin{array}{l}\text { Late } \\
\text { Transgressio }\end{array}$ & $\begin{array}{l}4.4 \\
\text { on }\end{array}$ & 82.3 & 3.62 & $5-20$ & $80-95$ & $30-70$ & $30-70$ & $35-70$ & $\begin{array}{l}\text { Fine bioclastic wackestone (lime-mud } \\
\text { foraminifers and pteropod fragments) }\end{array}$ \\
\hline Stillstand & 4.9 & 49.6 & 2.43 & $10-20$ & $80-90$ & $30-45$ & $55-70$ & $60-75$ & $\begin{array}{l}\text { Fine bioclastic wackestone (lime-mud } \\
\text { foraminifers and pteropod fragments) }\end{array}$ \\
\hline
\end{tabular}




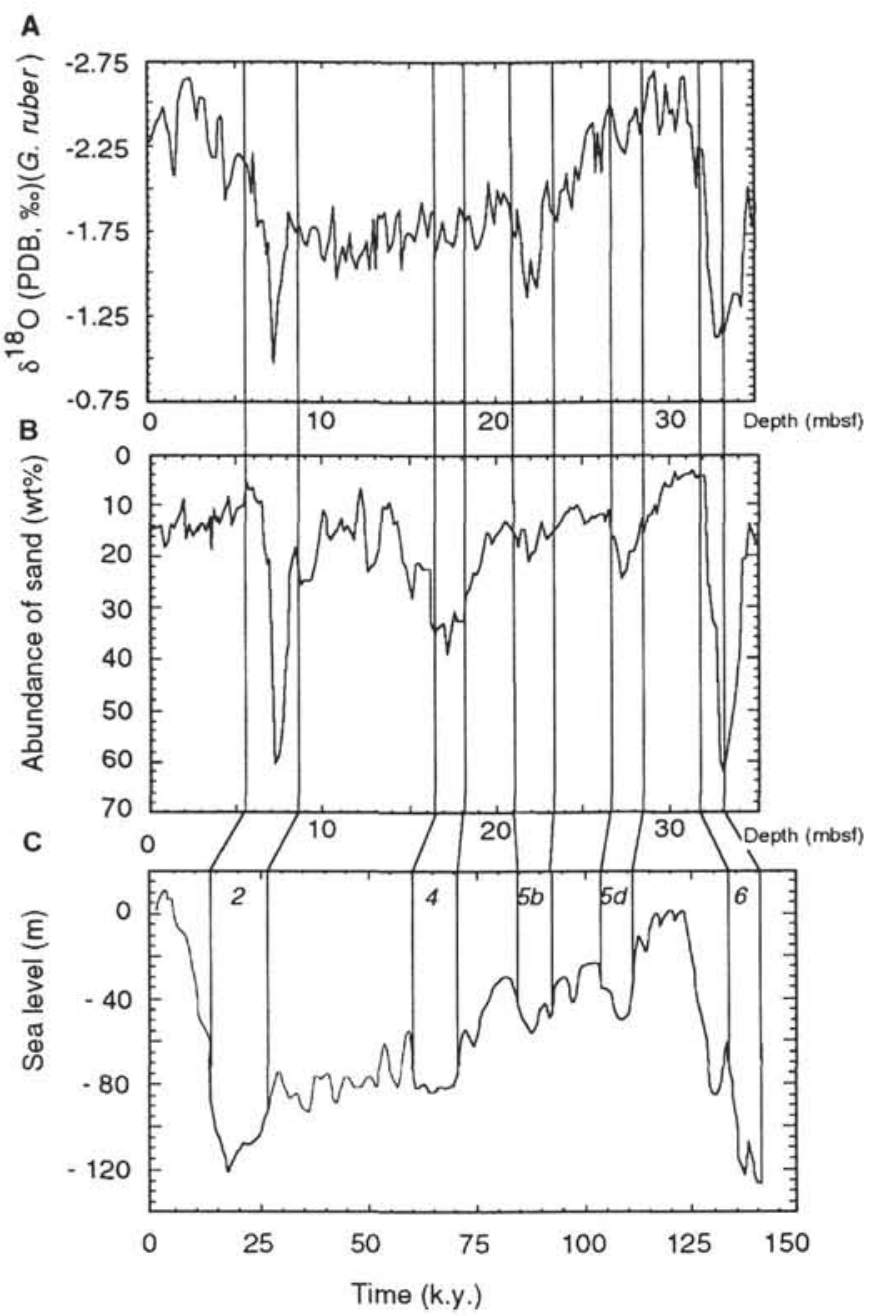

Figure 9. Comparison of the downcore variations from 0 to $35 \mathrm{mbsf}$ for (A) stable oxygen isotope ratios, (B) abundance of sand, and (C) an independent estimate of sea-level changes, based on the stable-isotope curve established by Shackleton (1987). Proposed correlations are discussed in the text. The numbers in the lower diagram represent successive oxygen-isotope stages. 